Çukurova Üniversitesi Mühendislik Mimarlık Fakültesi Dergisi, 31(1), 35-50 ss., Haziran 2016

Çukurova University Journal of the Faculty of Engineering and Architecture, 31(1), pp. 35-50, June 2016

\title{
Dolgu-Zemin Etkileşiminde Malzeme Modeli Etkisi
}

\author{
Zülal AKBAY ARAMA* ${ }^{* 1}$, S. Feyza ÇİNíCiOĞLU ${ }^{1}$ \\ ${ }^{1}$ Istanbul Üniversitesi, Mühendislik Fakültesi, İnşaat Mühendisliği Bölümü, İstanbul
}

Geliş tarihi: 23.12.2015 Kabul tarihi:09.03.2016

\section{Özet}

Kentleşme ve ulaşım sistemlerini oluşturan barajlar, limanlar, otoyol ve köprü yaklaşım dolguları gibi önemli inşaat mühendisliği uygulamalarının yumuşak temel zeminleri üzerine de yapılması gerekli olmaktadır. Temel zemini içinde yumuşak zeminler tek tabaka halinde veya tabakalanmış zemin profili içinde farklı kalınlıklarda bulunabilmektedirler. Bu makalede, farklı rijitlikteki ve kalınlıklardaki tabakalardan oluşan temel zemini profillerinin değişken geometrik özelliklere ve mukavemet parametrelerine sahip dolgularla birlikte davranışı, beş değişik malzeme modeliyle yapılan analizlerin sonuçları 1şığında parametrik olarak incelenmiştir. Sonuçların uygulamacılara dolgu-zemin etkileşiminin önemli davranış bileşenlerini değerlendirmek bakımından yararlı bilgiler sunacak nitelikte olduğu düşünülmektedir.

Anahtar Kelimeler: Dolgu, Tabakalanma, Kritik yükseklik, Malzeme modelleri, Zemin-yapı etkileşimi.

\section{Material Model Effects on Embankment-Soil Interaction}

\begin{abstract}
Embankment construction over soft foundation soils is usually required as part of the infrastructure projects such as dams, ports and harbours, highways and bridge abutments. Soft foundation soils may be encountered as thick deposits or as a layer of a stratified foundation system. In this paper, the problem of embankment construction on stratified soils consisting of a soft layer either at the top, just beneath the embankment loads or at the bottom beneath a stiffer soil stratum underlying the embankment were analysed. Many variables were considered in the parametrical analyses such as varying soil thicknesses, different sequences of layering, different embankment geometries. A large number of analyses were conducted by using five types of material models to find the main features of embankment-foundation interactive behaviour on the stratified soils and the role of adopted material models on the results.
\end{abstract}

Keywords: Embankment, Soil layering, Critical height, Material models, Soil-structure interaction.

\footnotetext{
* Yazışmaların yapılacağı yazar: Zülal AKBAY ARAMA, Mühendislik Fakültesi, İnşaat Mühendisliği Bölümü, İstanbul.zulalakbay@gmail.com
} 


\section{GİRIŞ}

Baraj, liman, otoyol ve köprü yaklaşım dolguları gibi önemli inşaat mühendisliği uygulamalarının yumuşak zeminler üzerine inşa edilmesi en karmaşık zemin mekaniği problemlerinden birisini oluşturmaktadır. Dolgular geniş alan kaplayan ve aktardıkları büyük yükler sebebi ile temel zeminini, genişlik ve derinlik olarak, büyük boyutlarda etkileyen yapılardır. Yumuşak zeminler ise düşük mukavemetleri ve yüksek sıkışabilirlik özellikleri nedeniyle problemli zeminler arasındadır. Sadece yumuşak zeminden oluşan kil birimlerinde bile zeminde meydana gelen yaşlanma, ıslanma-kuruma çevrimleri ve diğer kimyasal etkiler gibi etkenler nedeni ile zemin yüzeyinde kabuk tabakası oluşumu gözlenmektedir. Kabuk tabakası, altında yer alan yumuşak kil tabakası ile kıyaslandığında kil kabuk daha yüksek rijitlik ve dayanım değerine sahip olmaktadır. $\mathrm{Bu}$ sebeple yumuşak homojen bir zemin üzerine inşa edilen yapıların göçme şekli ile kabuk tabakasına veya tabakalanmış bir profile sahip olan zeminler üzerine inşa edilen yapıların göçme şekli birbirinden çokça farklı olmaktadır. Yumuşak temel zemini üzerinde yer alan kabuk tabakası zemini güçlendirmekte ve kabuğun kalınlığına bağlı olarak zemin taşıma kapasitesini arttırmaktadır [1]. Geoteknik uygulamalarında karşılaşılan birçok vakada yapılar farklı rijitlik özelliklerine ve farklı kalınlıklara sahip olan tabakalanmış temel zeminleri üzerine inşa edilmektedirler [2].

Günümüze kadar mükemmel plastik homojen zeminler hakkında sayısız çalışma yapılmış olmasına rağmen tabakalanmış zemin ortamındaki zemin-yap1 bütünleşik sisteminin analizinde elde edilecek efektif çözümlemeler hakkında sınırlı sayıda çalışma mevcuttur. Tabakalanmış temel zeminleri üzerine dolgu inşası probleminin diğer zemin-yap1 etkileşimi problemlerinden ayırt edici özelliği, bu problemlerde yapının kendisinin de zeminden inşa edilmiş olmasıdır. Bu bağlamda, Akbay Arama ve arkadaşları [3], yapmış oldukları çalışma ile yol genişletme çalışmalarında, farklı yapım süreçlerinin değişik temel zemini profilleri üzerindeki etkisini sonlu elemanlar yöntemi ile takip etmişlerdir. Söz konusu çalışmada Mohr
Coulomb malzeme modeli kullanılarak iki farklı rijitlikte zeminden oluşan tabakaların yapı altında yumuşak-sert kil ve sert- yumuşak kil sıralaması ile bulunması durumu için analizler yapılmıştır. Analizler sonucunda temel zemini profilinde bulunan kabuk tabakasının sistem stabilitesini arttırdığ1 ancak meydana gelen deformasyonlar bakımından değerlendirme yapıldığında ise kabuk tabakasının gerilme etkisini alttaki yumuşak tabakaya transfer etmesiyle deformasyonların alttaki yumuşak zemin tabakası içinde yoğunlaştırdığı belirlenmiştir. Üstte yumuşak zemin bulunması durumunda ise gerilmelerin yumuşak tabaka içerisindeki deplasmanlar ile absorbe edildiği gösterilmiştir. Akbay Arama ve Çinicioğlu [4], temel zemininin sadece yumuşak kil, sadece sert kil ve yumuşak-sert, sert-yumuşak kil olarak ardışık tabakalanması şeklinde dört farklı temel zemini tabakalanma profili için sonlu elemanlar yöntemi ile parametrik analizler yaparak mevcut bir dolgunun tek taraflı olarak genişletilmesi sırasında oluşan geoteknik problemleri irdelemişlerdir. Analizlerinde mevcut dolguyu ve genişletilen yolu Doğrusal Elastik, temel ortamını ise Pekleşen Zemin malzeme modelleri ile tanımlamışlardır. Analizlerinin sonucunda büyük deplasmanların mevcut dolgugenişletilmiş yol ara yüzeyinde meydana geldiğini, temel tabakalanma durumunun inşa prosedürünü ciddi oranda etkilediğini ve şekillendirdiğini, deformasyon değerlerinin üst ve alt sınır değerlerini sırasıyla saf yumuşak ve saf sert kilden oluşan zemin profillerinden elde edildiğini, yumuşak zeminin üstte bulunduğu durumda altta bulunduğu duruma nazaran daha yüksek güvenlik seviyesi elde edildiğini göstermişlerdir. Akbay Arama ve arkadaşları [5], tek ve çift taraflı dolgu genişletme çalışmalarının sebep olduğu problemleri inceleyerek yumuşak ve sert kil zeminden oluşan iki farklı tabakalanma durumu için meydana gelen deformasyonları ve stabilite problemlerini sonlu elemanlar ve limit denge programları ile analiz ederek karşılaştırmalı bir şekilde yorumlamalar getirmişlerdir. Dolgu ve genişletilmiş yolu Doğrusal Elastik, temel zemini ortamın ise Mohr Coulomb malzeme modelleri ile tanımlamışlardır. Analizlerin sonucunda üst tabakada yumuşak zemin bulunması durumunda tabaka kalınlığındaki artışın güvenlik düzeyini 
azalttığı ve bu durumun üst tabakada sert zemin bulunması durumda tersine döndüğü görülmüş, sonlu elemanlar yöntemi ile elde edilen güvenlik değerlerinin limit denge yöntemi ile elde edilen değerlerden daha yüksek olduğu hesaplanmıştır. Akbay Arama ve Çinicioğlu [6], yumuşak killerin iki katmanlı temel zemini profilinde alt veya üst tabakada farklı kalınlıklarda yer aldığı durumları ele alarak bu temel profilleri üzerine inşa edilebilecek olan dolgunun kritik yükseklik değerlerini araştırmışlardır. Söz konusu analizler için i- yumuşak kil-sert kil ve ii- sert kil-yumuşak kil şeklinde farklı iki rijitlikte kil katmanından oluşan ancak değişken tabaka kalınlıklarına sahip temel zemini profilleri belirlemişlerdir. Ayrıca değişik yapısal malzeme modellerinin (i-Mohr Coulomb, ii-Pekleşen Zemin, iii- Yumuşak Zemin) farklı temel zemini profilleri üzerindeki etkisini tüm yapım süreci boyunca tek kademe yükleme için modelleyerek takip etmişlerdir. Analizlerinin sonucunda malzeme modeli farklılıklarının etkisini sonuçlarda net bir şekilde gözlemiş ve Mohr Coulomb malzeme modelinden elde edilen yükseklikler ile Pekleşen Zemin ile Yumuşak Zemin modellerinden elde edilen kritik yükseklikler arasında 2-4 kata varan oranlarda farklılık hesaplamışlardır. Pekleşen ve Yumuşak Zemin malzeme modelleri ile tanımlanan yumuşak-sert kil temel profilinde ise Pekleşen Zemin malzeme modeli ile elde edilen yükseklik değerlerinin Yumuşak Zemin malzeme modeli ile elde edilen yükseklik değerlerinden daha fazla olduğunu görmüşlerdir. Tüm bu incelenen literatür çalışmaları göstermiştir ki; hem dolgu yükü altında bulunan yumuşak zeminlerin davranışının karmaşıklığı hem de inşa edilen dolgunun yap1 malzemesinin de zeminden oluşması sebebi ile dolgu-zemin sisteminin etkileşimli olarak davranış analizi gerekmektedir. $\mathrm{Bu}$ bağlamda yumuşak zeminler üzerine inşa edilen dolguların davranışı kendisini taşıyan temel zeminiyle birlikte incelendiğinde, yumuşak zemin üzerine uygulanan dolgu yükü, temel zemininin yeniden yerleşmesini sağlamakta ve yer değiştirme etkisi ile kütlenin hareketine karşı koyan bir direnç mekanizması mobilize olmaktadır. Temel zemininde oluşan bu yer değiştirmeler zeminin taşıma gücünü değiştirerek yumuşak zemin tabakalarında kayma etkisini ortaya çıkarmakta ve kayma etkileri zemin direncini aştığında ise temelin stabilitesi bozularak göçme durumuna ulaşılmaktadır. $\mathrm{Bu}$ sebeplerle dolgu-temel sistemi tasarımı yapılırken dolgunun geometrik ve geoteknik özelliklerinin temel zemini taşıma gücünün izin verdiği sınırlar içerisinde kalmasını sağlayacak bir analiz yöntemi ile belirlenmesi önemlidir. Dolgu-temel zemini etkileşimli sisteminin analizi amacıyla kullanılan sonlu elemanlar yöntemi, sayısal analiz yöntemlerinden en etkin ve sistematik olanıdır.

$\mathrm{Bu}$ makale kapsamında, farklı tabaka kalınlıklarına ve rijitlik değerlerine sahip olan tabakalanmış kil temeller değişik malzeme modelleri ile tanımlanarak, üzerlerinde yer alan dolguların ani yükleme koşullarında göçmeden inşa edilebileceği kritik yükseklik değerleri araştırılmış ve bu yolla göçme mekanizmalarının şekilleri, deformasyon değerleri ve deformasyon dağılım bölgeleri Plaxis sonlu elemanlar programı ile iki boyutlu düzlem deformasyon koşullarında değerlendirilmiştir. Yapılan çalışmalar göstermiştir ki, gerek dolgu gerekse temel zemini profili için kullanılan geoteknik parametrelerin hesaplanmas1 tasarımda dikkat edilmesi gereken en önemli husustur. Hesaplanan geoteknik parametrelerin sistem davranışını temsil edecek nitelikte malzeme modelleri ile kullanımı ise gerilme dağılımları, deformasyonlar, göçme mekanizmaları gibi tipik davranış özellikleri üzerinde ciddi bir etkiye sahiptir.

\section{DOLGU-ZEMIN ETKÍLEŞIMI IÇIN PARAMETRIK ANALIZLER}

Dolgu tasarımında dikkat edilmesi gereken en önemli nokta hem dolgu altındaki temel zemini ortamının değişken yapıya sahip olması hem de inşa edilen dolgunun yapısal malzemesinin zeminden oluşmasıdır. Bu durum sebebiyle yapısal sistemin dolgu olduğu uygulamalarda inceleme aşamasında, inşa sırasında ve inşadan sonraki davranış bir bütün olarak ele alınmalı ve ortaya çıkabilecek sorunlar mühendislik bakış açısı ile değerlendirilerek tasarım aşamasında çözüme yönelik çalışmalar yapılmalıdır. Tasarım aşamasında zemin-yapı bütünleşik sisteminin 
davranışını şekillendiren en temel özellikler; malzeme davranış modeli ve bu modele bağlı olarak hesaplanan malzeme özellikleridir. $\mathrm{Bu}$ makale kapsamındaki geoteknik özelliklerin belirlenmesinde literatürden büyük ölçüde faydalanılmış ve en gerçekçi bütünsel davranışın elde edilebilmesi amaciyla hem dolgu hem de zemin ortamı için farklı malzeme modelleri kullanılmıştır. Dolgu zemininin tanımlanması için; Mohr Coulomb (MC), Pekleşen Zemin (HS) ve Pekleşen Zemin Küçük Birim Deformasyon Rijitliği (HS_SS) malzeme modelleri; temel zeminlerinin tanımlanması için; i-Mohr Coulomb (MC), ii-Pekleşen Zemin (HS) iii-Pekleşen Zemin Küçük Birim Deformasyon Rijitliği (HS_SS) ivYumuşak Zemin (SS) v-Modifiye Cam Kili (MCC) malzeme modelleri seçilmiştir. Ayrıca analizler için Profil 1: yumuşak kil (YK)-sert kil (SK) ve Profil 2: sert kil (SK)-yumuşak kil (YK) şeklinde farklı iki rijitlikte kil katmanından oluşan ancak değişken tabaka kalınlıklarına (1-3-6-18-36-125 metre) sahip zemin profilleri belirlenmiştir. Dolgunun inşa şeklinin ve malzeme parametrelerinin sistem davranışı üzerindeki etkisinin belirlenmesi amacı ile dolgu malzeme özelliklerinde değişiklik yapılmış ve elde edilen beş adet dolgu (D1, D2, D3, D4, D5) ile çok değişkenli analizler tekrarlanmıştır. Dolgu 1 (D1), diğer dolgu uygulaması örneklerinin referansı olarak kullanılmıştır. (1/2) şev eğiminde inşa edilen Dolgu 1 için [7]'den faydalanılarak birim hacim ağırlık değeri $20 \mathrm{kN} / \mathrm{m}^{3}$, kayma mukavemeti parametreleri $\mathrm{c}=5 \mathrm{kPa}$ ve $\phi=30^{\circ}$ olarak seçilmiştir. Dolgu 2'de (D2), D1'in geoteknik parametreleri aynen kullanılmış ancak dolgu-zemin ara yüzeyine geotekstil malzeme serilerek dolgu güçlendirilmiştir. Dolgu 3'de (D3), şev eğimi (1/2) olarak kullanılmış, birim hacim ağırlığı değeri 18 $\mathrm{kN} / \mathrm{m}^{3}$ seçilerek dolgu D1'e göre hafifletilmiş ve kayma mukavemeti parametreleri $\mathrm{c}=3 \mathrm{kPa}$ ve $\phi=25^{\circ}$ seçilerek dolgu malzemesi zayıflatılmıştır. Dolgu 4'de (D4), birim hacim ağırlı̆̆ $20 \mathrm{kN} / \mathrm{m}^{3}$, kayma mukavemeti parametreleri $\mathrm{c}=1 \mathrm{kPa}$ ve $\phi=22^{\circ}$ seçilerek D1'e göre malzeme zayıflatılmıştır. Dolgu 5'de (D5), şev eğiminin göçme davranışına etkisi araştırılmış ve eğim değeri (1/1) oranına azaltılarak D1 ile aynı geoteknik parametreler kullanılmıştır. Ayrıca D1 için her iki zemin profilinde ve tanımlanan tüm temel zemini malzeme modellerinde analizler sonucu meydana gelen toplam deplasman değerleri elde edilerek yorumlanmıştır. Yapılan tüm parametrik çalışmalar sonucunda dolgu-temel zemini etkileşimli davranışını en gerçekçi şekilde temsil edeceği düşünülen malzeme modelleri seçilerek D1'in üst tabaka kalınlığının 1-6-18 metre olması durumlarında her iki zemin profilinde analizler tekrarlanmıştır. Aşağıda, ilk olarak makale kapsamında kullanılan malzeme davranış modelleri anlatılmış ve ardından dolgu-zemin ortamına ait geometrik-geoteknik özelliklerin detayları verilmiştir. Makale kapsamında, iki boyutlu ortamda ve eksenel simetrik koşullarda yapılan analizler için sonlu elemanlar yöntemi ile çalışan Plaxis V 2011.02 programı kullanılmıştır. Dolgu ve temel zemini ortamının modellenmesinde program dâhilinde bulunan malzeme modellerinden i-MC, ii-HS, iii-HS_SS, iv-SS ve vMCC seçilmiştir. Söz konusu malzeme modellerinden MC'de akma yüzeyinde zemin lineer elastik mükemmel plastik malzeme olarak davranış sergilemektedir. $\mathrm{Bu}$ yolla $\mathrm{MC}$ model çözümlerinde zemin için tek ve sabit bir rijitlik parametresi kullanmaktadır. Geoteknik problemlerine ilk yaklaşımda ve öncül analizlerde tercih edilmekte olan bu yöntemde hesaplamalar hızlıdır. Model stabilite hesaplamaları için idealdir ancak verdiği deformasyon değerleri gerçekçi değildir. MC modelde kullanılan parametreler; E Young modülü $\left[\mathrm{kN} / \mathrm{m}^{2}\right], v$ poisson oranı [-], c kohezyon $\left[\mathrm{kN} / \mathrm{m}^{2}\right], \phi$ sürtünme açısı $\left[{ }^{\circ}\right], \psi$ genleşme açısı $\left[{ }^{\circ}\right]$ şeklindedir [8]. HS malzeme modeli, hem yumuşak hem de sert killer gibi farklı davranış özellikleri gösteren zeminlerin modellenmesinde kullanılan ileri düzeyli bir modeldir. MC modeldeki gibi göçme durumu $\phi, \mathrm{c}$, $\psi$ ile tanımlanmaktadır. Bununla birlikte rijitlik parametreleri üç farklı değer ile daha doğru olarak ifade edilebilmektedir: Drenajlı üç eksenli deneyden elde edilen referans sekant rijitliğgi $\mathrm{E}_{50}{ }^{\text {ref, }}$, referans üç eksenli boşaltma/yeniden yükleme rijitliği $E_{u r}{ }^{\text {ref }}$ ve birincil ödometre yüklemesi için referans tanjant rijitliği $\mathrm{E}_{\text {oed }}{ }^{\text {ref }}$. HS model gerilmeye bağlı rijitlik modüllerini dikkate almaktadır. $\mathrm{Bu}$ durum basınç ile birlikte tüm rijitliklerin artması anlamına gelmektedir. Referans basınç değeri $100 \mathrm{kPa}$ (1 bar) olarak değerlendirmeye alınmaktadır. HS_SS modelde, HS modeline ilave 
olarak küçük birim deformasyon değerlerinde zeminin artan rijitliği de dikkate alınmaktadır. Bu davranış HS_SS modelde bir başlangıç birim deformasyon geçmişi modülü ve iki başlangıç malzeme parametresi $\left(\mathrm{G}_{0}{ }^{\text {ref }}, \gamma_{0.7}\right)$ tanımlanmasi ile anlatılmaktadır. $\mathrm{G}_{0}{ }^{\text {ref }}$, küçük birim deformasyon kayma modülünü ve $\gamma_{0.7}$, kayma modülünün küçük deformasyon kayma modülüne göre $\% 70$ azalımındaki birim deformasyon seviyesini tariflemektedir. HS_SS Modelin tanımlanmasında kullanılan diğer parametreler HS modelle aynıdır. Yüksek sıkışabilirlik özellikleri sebebi ile normal konsolide killer, killi siltler ve turba zeminler yumuşak zeminler olarak ifade edilmektedirler. Yumuşak zeminleri tanımlamakta kullanılan ileri düzey bir model olan SS, Cam Kili teorisi ve kritik durum zemin mekaniği bakış açısı çerçevesinde geliştirilmiştir. Modelde MC göçme kriteri mevcut olup, diğer parametreler: $\lambda^{*}$ modifiye sıkışma indeksi, $\kappa^{*}$ modifiye şişme indeksi, $\nu_{u r}$ boşaltma/yeniden yükleme poisson oranı şeklindedir. MCC malzeme modeli dünya çapında kabul görmüş ileri düzeyli bir modeldir. Bu model normal konsolide kil zeminlerin davranışını ifade etmek için oluşturulmuştur. Farklı zeminlerin tanımlanmasında kullanıldıklarında çok büyük kayma gerilmelerinin oluşmasına izin verebilmektedir bu sebeple modelin güvenlik analizlerinde ve pratik uygulamalarda kullanılması önerilmemektedir. MCC Modelde kullanılan parametreler: : $\lambda$ Cam kili sıkışma indeksi, $\kappa$ Cam kili şişme indeksi, $M$ kritik durum çizgisinin tanjantı, $e_{\text {init }}$ başlangıç boşluk oranı, $v_{u r}$ boşaltma/yeniden yükleme poisson oranı şeklindedir $[8,9]$.

\subsection{Dolgunun Geometrik ve Geoteknik Özellikleri}

Analizlerde kullanılan dolgunun taban genişliği 90 metredir ve platform genişliği kritik dolgu yüksekliğine bağlı olarak değişmektedir (Şekil 1). Dolgunun şev eğimi düşey/yatay: 1/1, 1/2 olarak iki farklı eğimde koordinatlandırılarak sayısal analiz programına tanımlanmıştır. Sonlu elemanlar yönteminin kullanılmış olduğu analizlerde doğru tahminler sağlamak ancak model parametrelerinin doğru seçimi ile sağlanabilmektedir. Bu makalede kullanılan dolgunun özelliklerinin belirlenmesinde
Brinkgreve ve arkadaşları (2010) tarafindan kum zeminler için geliştirilmiş olan ampirik formüllerden faydalanılmıştır [10]. Formüllerde, RD değeri yüzdelik olarak göreceli sıkılık değerini vermektedir. Eşitlik (1) yardımı ile bilinen doymamış birim hacim ağırlığı değerinden RD değeri hesaplanabilmekte ve hesaplanan RD değeri ile Eşitlik (2)'den de doygun birim hacim ağırlığı elde edilebilmektedir.

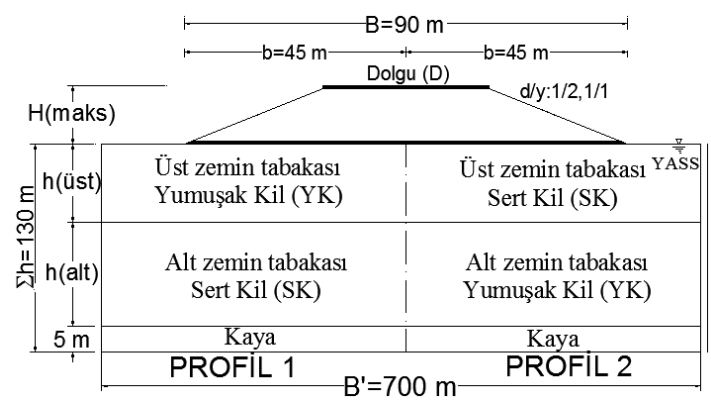

Şekil 1. Zemin profilleri ve dolgu geometrik kesiti

$$
\begin{array}{ll}
\gamma_{\text {unsat }}=15+4.0 \mathrm{RD} / 100 & {\left[\mathrm{kN} / \mathrm{m}^{3}\right]} \\
\gamma_{\text {sat }}=19+1.6 \mathrm{RD} / 100 & {\left[\mathrm{kN} / \mathrm{m}^{3}\right]}
\end{array}
$$

Seçilen bir referans basıncı (program tarafından $\mathrm{P}^{\text {ref }}$ değeri $100 \mathrm{kN} / \mathrm{m}^{2}$ olarak atanmıştır) değerine bağlı olarak HS ve HS SS model için gerekli olan rijitlik parametreleri Eşitlik (3), (4), (5), (6) ile hesaplanabilmektedir.

$$
\begin{array}{ll}
\mathrm{E}_{50}{ }^{\mathrm{ref}}=60000 \mathrm{RD} / 100 & {\left[\mathrm{kN} / \mathrm{m}^{2}\right]} \\
\mathrm{E}_{\mathrm{oed}}{ }^{\mathrm{ref}}=60000 \mathrm{RD} / 100 & {\left[\mathrm{kN} / \mathrm{m}^{2}\right]} \\
\mathrm{E}_{\mathrm{ur}}{ }^{\mathrm{ref}}=180000 \mathrm{RD} / 100 & {\left[\mathrm{kN} / \mathrm{m}^{2}\right]} \\
\mathrm{G}_{0}{ }^{\mathrm{ref}}=60000+68000 \mathrm{RD} / 100 & {\left[\mathrm{kN} / \mathrm{m}^{2}\right]}
\end{array}
$$

Eşitlik (7) $\mathrm{G}_{\mathrm{s}}=0,722 \mathrm{G}_{0}$ 'daki kayma birim deformasyonu $\gamma_{0.7}$ değerini ifade etmektedir.

$$
\gamma_{0.7}=(2-\mathrm{RD} / 100) 10^{-4} \quad[-]
$$

E’ değeri Eşitlik (8)'den hesaplanmaktadır.

$$
E^{\prime}=\left[\left(1+v^{\prime}\right)\left(1-2 v^{\prime}\right) /\left(1-v^{\prime}\right)\right] E_{\text {oed }} \quad\left[\mathrm{kN} / \mathrm{m}^{2}\right]
$$

Tanımlanmış olan bu eşitlikler yardımı ile MC, HS, HS_SS model için hesaplanmış dolgu geoteknik parametreleri Çizelge 1'de verilmiştir. 
Çizelge 1. Yol dolgusunun geoteknik özellikleri

\begin{tabular}{|c|c|c|c|c|c|c|c|c|c|c|}
\hline $\begin{array}{l}\text { Temel Zemini } \\
\text { Malzeme Modeli }\end{array}$ & & & & & HS & & & & & $\mathrm{CC}$ \\
\hline Zemin Rijitliği & YK & SK & YK & SK & YK & SK & YK & SK & YK & SK \\
\hline Drenaj tipi & Und(C) & Und(C) & Und(A) & Und(A) & Und(A) & Und(A) & Und(A) & Und(A) & Und(A) & Und(A) \\
\hline$\gamma_{\text {unsat }}\left(\mathrm{kN} / \mathrm{m}^{3}\right)$ & 16,5 & 19,5 & 16,5 & 19,5 & 16,5 & 19,5 & 16,5 & 19,5 & 16,5 & 19,5 \\
\hline $\mathrm{e}_{0}$ & 2,1 & 0,8 & 2,1 & 0,8 & 2,1 & 0,8 & 2,1 & 0,8 & 2,1 & 0,8 \\
\hline $\mathrm{S}_{\mathrm{u}}(\mathrm{kPa})$ & 20 & 80 & - & - & - & - & - & - & - & - \\
\hline $\mathrm{E}^{\prime}(\mathrm{kPa})$ & 10000 & 40000 & - & - & - & - & - & - & - & - \\
\hline $\mathrm{E}_{\mathrm{ur}}^{\mathrm{ref}}(\mathrm{kPa})$ & - & - & 800 & 8500 & 800 & 8500 & - & - & - & - \\
\hline $\mathrm{E}_{50}{ }^{\mathrm{ref}}(\mathrm{kPa})$ & - & - & 850 & 9000 & 850 & 9000 & - & - & - & - \\
\hline $\mathrm{E}_{\text {oed }}{ }^{\text {ref }}(\mathrm{kPa})$ & - & - & 8000 & 30000 & 8000 & 30000 & - & - & - & - \\
\hline$*_{v-v_{u}-v_{u r}^{\prime}}^{\prime}$ & 0,495 & 0,495 & 0,2 & 0,2 & 0,2 & 0,2 & 0,2 & 0,2 & 0,2 & 0,2 \\
\hline $\mathrm{c}_{\text {ref }}^{\prime}\left(\mathrm{kN} / \mathrm{m}^{2}\right)$ & - & - & 1 & 25 & 1 & 25 & 1 & 25 & 1 & 25 \\
\hline$\varphi^{\prime}\left({ }^{\circ}\right)$ & - & - & 23 & 26 & 23 & 26 & 23 & 26 & 23 & 26 \\
\hline$\gamma_{0,7}$ & - & - & - & - & 0,056 & 0,1 & - & - & - & - \\
\hline $\mathrm{G}_{0}^{\mathrm{ref}}\left(\mathrm{kN} / \mathrm{m}^{2}\right)$ & - & - & - & - & 7000 & 30000 & - & - & - & - \\
\hline$\lambda *$ & - & - & - & - & - & - & 0,12 & 0,045 & - & - \\
\hline $\mathrm{K}^{*}$ & - & - & - & - & - & - & 0,02 & 0,009 & - & - \\
\hline$\lambda$ & - & - & - & - & - & - & - & - & 0,372 & 0,036 \\
\hline $\mathrm{K}$ & - & - & - & - & - & - & - & - & 0,062 & 0,0162 \\
\hline$M$ & - & - & - & - & - & - & - & - & 0,8984 & 1,0267 \\
\hline
\end{tabular}

Analizlerde kullanılan geotekstil malzemenin EA eksenel rijitlik değeri Boogert ve arkadaşları (2012) tarafindan DIN EN ISO 10319 standartlarına göre uygulanan beş çekme deneyinden elde edilen $2269 \mathrm{kN} / \mathrm{m}$ değeri olarak kullanılmıştır [11].

\subsection{Temel Zemini Profili Geometrik ve Geoteknik Özellikleri}

Tabakalanmış temel zeminleri üzerinde yer alan dolgulardaki kritik yükseklik değerinin belirlenmesi amacı ile birbirine zit rijitlik özelliğine sahip kil tabakalarının artarda sıralama durumu için zemin profilleri oluşturulmuştur (Şekil 1). Üstte bulunan kil tabakalarının kalınlıkları 1-3-6-18-36-125 metre olacak şekilde değişkendir. Yapılan modellemelerde zemin ortamının toplam tabaka kalınlığ 130 m olacak şekilde seçilmiştir. Zemin profílinde yeraltı su seviyesi zemin üst yüzeyindedir. Temel zemininin dayanım ve rijitlik özelliklerinin belirlenmesinde, [8, 12]'den faydalanılmıştır. Söz konusu çalışmalarda, zeminin geoteknik parametrelerinin belirlenmesi amacı ile ödometre ve üç eksenli testlerden oluşan kapsamlı bir deneysel veri dizisi oluşturularak Plaxis programında üç eksenli ve ödometre deneyleri modellenerek yumuşak ve sert Bangkok kili için MC, HS, HS_SS, SS malzeme modellerine ait parametreler denetlenmiştir. Bu makalede söz konusu parametreler kullanılmış olup, permeabilite katsayıları $\mathrm{x}$ ve y yönlerinde anizotropi etkisi göz önüne alınarak tanımlanmıştır $\left(\mathrm{k}_{\mathrm{x}(\mathrm{YK})}=8 \times 10^{-05} \mathrm{~m} / \mathrm{g}, \mathrm{k}_{\mathrm{y}(\mathrm{YK})}=4 \times 10^{-05} \mathrm{~m} / \mathrm{g}, \mathrm{k}_{\mathrm{x}(\mathrm{SK})}=\right.$ $\left.8 \times 10^{-04} \mathrm{~m} / \mathrm{g}, \mathrm{k}_{\mathrm{y}(\mathrm{SK})}=4 \times 10^{-04} \mathrm{~m} / \mathrm{g}\right)$. Çizelge 2 ' de $\mathrm{MC}$, HS, HS_SS, SS, MCC malzeme modelleri için makale kapsamında kullanılacak olan parametreler özetlenmiştir.

\section{SAYISAL ANALIZLER VE DEĞERLENDİRMELER}

Plaxis V 2011.02 programında yapılan 1368 adet analizde, dolgunun tek kademede drenajsız olarak yüklenmesi (toptan) durumunda göçmeden inşa edilebileceği maksimum yükseklik değeri "kritik yükseklik" olarak tanımlanmış ve elde edilen veriler bu parametre 1 şı̆̆ında yorumlanmıştır. 
Analizlerde dolgu kritik yüksekliği değerinin tayini için 0,5 metre hassasiyet kullanılarak, inşa drenajsız koşullarda plastik faz (konsolidasyon süresi tanımlanmaksızın) ile gerçekleştirilmiş ve inşa sonrası yapılan güvenlik analizleri ile güvenlik sayısı değerini 1'e yakınsayan değer kritik yükseklik değeri olarak elde edilmiştir. Ayrıca sonlu elemanlar yönteminde kullanılan ağ yoğunluğunun analiz sonuçlarına etkisinin değerlendirilmesi amacıyla geniş - orta ve çok sıkı olarak seçilen ağlar ile ayrı ayrı analizler tekrarlanmıştır. Orta-çok sıkı olarak tanımlanan sonlu elemanlar ağlarında yapılan analizlerde aynı sonuçlara yaklaşıldığı görülmüştür. Makale içeriğindeki değişkenlerin çokluğu sebebi ile optimum süre kullanımı açısından sonlu elemanlar ağı "orta" yoğunlukta modellenerek çalışmalar gerçekleştirilmiştir.

Çizelge 2. Temel zemini geoteknik özellikleri

\begin{tabular}{|c|c|c|c|c|c|c|}
\hline \multirow{2}{*}{ Malzeme Modeli } & \multicolumn{3}{|c|}{ Dolgu 1-2-4-5 } & \multicolumn{3}{c|}{ Dolgu 3 } \\
\cline { 2 - 7 } & MC & HS & HS_SS & MC & HS & HS_SS \\
\hline $\mathrm{RD}$ & 125 & 125 & 125 & 75 & 75 & 75 \\
\hline$\gamma_{\text {unsat }}\left(\mathrm{kN} / \mathrm{m}^{3}\right)$ & 20 & 20 & 20 & 18 & 18 & 18 \\
\hline $\mathrm{e}_{0}$ & 0,5 & 0,5 & 0,5 & 0,5 & 0,5 & 0,5 \\
\hline $\mathrm{E}^{\prime}(\mathrm{kPa})$ & 67500 & - & - & 40500 & - & - \\
\hline $\mathrm{E}_{50}{ }^{\text {ref }}(\mathrm{kPa})$ & - & 75000 & 75000 & - & 45000 & 45000 \\
\hline $\mathrm{E}_{\text {oed }}{ }^{\text {ref }}(\mathrm{kPa})$ & - & 75000 & 75000 & - & 45000 & 45000 \\
\hline $\mathrm{E}_{\text {ur }}{ }^{\text {ref }}(\mathrm{kPa})$ & - & 225000 & 225000 & - & 135000 & 135000 \\
\hline $\mathrm{V}^{\prime}$ & 0,2 & - & - & 0,2 & - & - \\
\hline $\mathrm{V}_{\text {ur }}^{\prime}$ & - & 0,2 & 0,2 & - & 0,2 & 0,2 \\
\hline $\mathrm{c}^{\prime}{ }_{r e f}(\mathrm{kPa})$ & 5 & 5 & 5 & 3 & 3 & 3 \\
\hline$\varphi^{\prime}\left({ }^{\circ}\right)$ & 30 & 30 & 30 & 25 & 25 & 25 \\
\hline $\mathrm{k}_{\mathrm{x}}(\mathrm{m} / \mathrm{gün})$ & 0,3145 & 0,3145 & 0,3145 & 0,3145 & 0,3145 & 0,3145 \\
\hline $\mathrm{k}_{\mathrm{y}}(\mathrm{m} / \mathrm{gün})$ & 0,3145 & 0,3145 & 0,3145 & 0,3145 & 0,3145 & 0,3145 \\
\hline$\gamma 0,7$ & - & - & $7,50 \mathrm{E}-05$ & - & - & $1,25 \mathrm{E}-04$ \\
\hline $\mathrm{G}_{0}{ }^{\text {ref }}(\mathrm{kPa})$ & - & - & 145000 & - & - & 111000 \\
\hline
\end{tabular}

Değişken üst tabaka kalınlıklarında olan temel zeminlerinin beş farklı malzeme modeli (MC, HS, HS_SS, SS, MCC) ile dolgunun sadece MC malzeme modeli ile tanımlanması durumunda inşa edilebilecek olan kritik dolgu yüksekliği değerleri Çizelge 3'de verilmiştir. Çizelgede bahsi geçen farklı dolgulara (D1, D2, D3, D4, D5) ait özellikler Çizelge 4'de detaylandırılmıştır. Çizelge 3'de sunulmuş olan verilerin daha anlamlı kılınması için Şekil 2'de aynı malzeme modeli ile tanımlanmış olan temel zeminleri için, üstte sırası ile yumuşak ve sert kil bulunması durumlarında dolgu özelliklerinin (Dolgu 1-2-3-4-5) kritik yükseklik değerleri üzerindeki etkisi verilmiştir. Grafiklerin isimlendirmesinde kullanılan (1) alt indisi üst tabakada yumuşak kil, (2) alt indisi ise üst tabakada sert kil bulunması durumunu, (a) MC, (b) HS, (c) HS_SS, (d) SS, (e) MCC malzeme modellerinde yapilan analizleri temsil etmektedir.
Şekil 2( $\left.\mathrm{a}_{1}\right)^{\prime}$ de üst tabakanın küçük kalınlıklardaki yumuşak kilden oluşması durumunda, dolgu geoteknik ve geometrik özelliklerinin sistem davranışına etkisi daha net bir şekilde gözlemlenmektedir. D1 ve D2 dolgularında en fazla kritik dolgu yüksekliğine ulaşıldığı ve geotekstil ile yapılan iyileştirmenin dolgu yüksekliği üzerinde etkisi olmadığı görülmüştür. Ayrıca üst tabakada yumuşak zemin bulunması durumlarında, tabaka kalınlığının 15-20 metre değerlerine kadar tüm dolgularda azalan kritik dolgu yüksekliği değeri gösterirken; bu kalınlık değerinden fazla yumuşak zemin bulunması durumunda, 5 metre değerinde sabit kalmaktadır. $\mathrm{Bu}$ durum, sistem davranışında dolgu malzemesi özelliklerinin artık etkili olmadığının yani sistemin yumuşak zemin deformasyonları tarafından yönetildiğinin bir göstergesidir. 
Çizelge 3. Farklı malzeme modellerine ve tabakalanma durumlarına sahip temel zeminleri üzerinde yer alan Dolgu 1-2-3-4-5 (MC) için elde edilen kritik yükseklik değerleri

\begin{tabular}{|c|c|c|c|c|c|c|c|c|c|c|}
\hline \multicolumn{11}{|c|}{ D 1 (MC) } \\
\hline \multirow{4}{*}{$\begin{array}{c}\text { UST TABAKA } \\
\text { KALINLIĞI (m) }\end{array}$} & \multicolumn{10}{|c|}{ Temel Zemini Malzeme Modeli } \\
\hline & \multicolumn{2}{|c|}{ MC } & \multicolumn{2}{|c|}{ HS } & \multicolumn{2}{|c|}{ HS_SS } & \multicolumn{2}{|c|}{ SS } & \multicolumn{2}{|c|}{ MCC } \\
\hline & YK & SK & YK & SK & YK & SK & YK & SK & YK & SK \\
\hline & \multicolumn{2}{|c|}{$\mathrm{hcr}(\mathrm{m})$} & \multicolumn{2}{|c|}{$\mathrm{hcr}(\mathrm{m})$} & \multicolumn{2}{|c|}{$\mathrm{hcr}(\mathrm{m})$} & \multicolumn{2}{|c|}{$\mathrm{hcr}(\mathrm{m})$} & \multicolumn{2}{|c|}{$\mathrm{hcr}(\mathrm{m})$} \\
\hline 1 & 13 & 5 & 1,5 & 4,5 & 2 & 4,5 & 1,5 & 3,5 & 1 & 1,5 \\
\hline 3 & 9 & 5,5 & 1,5 & 7 & 2 & 7 & 1,5 & 5,5 & 1 & 2 \\
\hline 6 & 7 & 6 & 1,5 & 9,5 & 2 & 9,5 & 1,5 & 8 & 1 & 2 \\
\hline 18 & 5,5 & 8 & 1,5 & 14,5 & 2 & 15 & 1,5 & 11 & 1 & 2 \\
\hline 36 & 5 & 11,5 & 1,5 & 14,5 & 2 & 15 & 1,5 & 11 & 1 & 2 \\
\hline 125 & 5 & 22 & 1 & 14,5 & 2 & 15 & 1,5 & 11 & 1 & 2 \\
\hline \multicolumn{11}{|c|}{ D 2 (MC) } \\
\hline 1 & 13 & 5,5 & 3,5 & 7 & 3,5 & 7 & 4,5 & 6,5 & 2 & 3 \\
\hline 3 & 9,5 & 5,5 & 3 & 11,5 & 3 & 11,5 & 3 & 10,5 & 1,5 & 4,5 \\
\hline 6 & 8 & 6 & 3 & 15,5 & 3 & 14,5 & 3 & 12,5 & 1,5 & 6 \\
\hline 18 & 6,5 & 8 & 3 & 20,5 & 2,5 & 20 & 3 & 22 & 1,5 & 6 \\
\hline 36 & 5,5 & 11,5 & 3 & 22 & 2,5 & 22 & 3 & 22 & 1,5 & 6 \\
\hline 125 & 5 & 22 & 3 & 22 & 2,5 & 22 & 3 & 22 & 1,5 & 6 \\
\hline \multicolumn{11}{|c|}{ D 3 (MC) } \\
\hline 1 & 11 & 6 & 1,5 & 4,5 & 1,5 & 5 & 2 & 4,5 & 1 & 1,5 \\
\hline 3 & 9 & 6 & 1,5 & 7 & 1,5 & 7,5 & 2 & 6 & 1 & 1,5 \\
\hline 6 & 7,5 & 7 & 1,5 & 9,5 & 1,5 & 10,5 & 2 & 8,5 & 1 & 1,5 \\
\hline 18 & 6 & 9 & 1,5 & 15,5 & 1,5 & 16 & 2 & 10,5 & 1 & 1,5 \\
\hline 36 & 5,5 & 13 & 1,5 & 15,5 & 1,5 & 16 & 2 & 10,5 & 1 & 1,5 \\
\hline 125 & 5,5 & 22 & 1 & 15,5 & 1,5 & 16 & 2 & 10,5 & 1 & 1,5 \\
\hline \multicolumn{11}{|c|}{ D 4 (MC) } \\
\hline 1 & 7,5 & 5 & 1 & 4 & 1 & 4 & 1 & 3,5 & 0,5 & 1 \\
\hline 3 & 7 & 5,5 & 1 & 6,5 & 1 & 6,5 & 1 & 5 & 0,5 & 1 \\
\hline 6 & 6 & 6 & 1 & 8,5 & 1 & 8,5 & 1 & 7 & 0,5 & 1 \\
\hline 18 & 5 & 8,5 & 1 & 8 & 1 & 11,5 & 1 & 7 & 0,5 & 1 \\
\hline 36 & 5 & 8,5 & 1 & 6 & 1 & 11,5 & 1 & 7 & 0,5 & 1 \\
\hline 125 & 5 & 10,5 & 1 & 6,5 & 1 & 11,5 & 1 & 7 & 0,5 & 1 \\
\hline \multicolumn{11}{|c|}{ D 5 (MC) } \\
\hline 1 & 8 & 5 & 1,5 & 4,5 & 1,5 & 4,5 & 1,5 & 3,5 & 0,5 & 1 \\
\hline 3 & 7,5 & 5,5 & 1,5 & 6,5 & 1,5 & 6,5 & 1,5 & 5 & 0,5 & 1 \\
\hline 6 & 6,5 & 5,5 & 1,5 & 8,5 & 1,5 & 8,5 & 1,5 & 7,5 & 0,5 & 1 \\
\hline 18 & 5 & 7,5 & 1,5 & 12 & 1,5 & 12 & 1,5 & 7,5 & 0,5 & 1 \\
\hline 36 & 5 & 10 & 1,5 & 12 & 1,5 & 12 & 1,5 & 7,5 & 0,5 & 1 \\
\hline 125 & 5 & 12 & 1,5 & 12 & 1,5 & 12 & 1,5 & 7,5 & 0,5 & 1 \\
\hline
\end{tabular}

Çizelge 4. Dolgu 1-2-3-4-5'e ait geometrik ve geoteknik detaylar

\begin{tabular}{|c|c|c|c|c|c|}
\hline Dolgu No & Şev eğimi & İyileştirme & $\gamma\left(\mathrm{kN} / \mathrm{m}^{3}\right)$ & $\mathrm{c}(\mathrm{kPa})$ & $\phi\left(^{\circ}\right)$ \\
\hline Dolgu 1 & $1 / 2$ & - & 20 & 5 & 30 \\
\hline Dolgu 2 & $1 / 2$ & Var & 20 & 5 & 30 \\
\hline Dolgu 3 & $1 / 2$ & - & 18 & 3 & 25 \\
\hline Dolgu 4 & $1 / 2$ & - & 20 & 1 & 22 \\
\hline Dolgu 5 & $1 / 1$ & - & 20 & 5 & 30 \\
\hline
\end{tabular}

Şekil 2(a $\left.a_{2}\right)$ 'de üstte sert zeminin bulunduğu durumlarda, 18 metre kalınlığına kadar tüm dolgularda aynı davranış şekli ve kritik dolgu 42 yüksekliği hesaplanmıştır. Bu kalınlık değerinden sonra, aynı anda, hem dolgu malzemesi kayma mukavemeti parametrelerinin azaltılması hem de 
birim hacim ağırlığının azaltılması ulassılabilecek olan kritik yükseklik değerini olumlu bir şekilde etkilemiştir.

$\mathrm{Bu}$ davranışın sebebi, dolgunun hafifletilmesi ile yumuşak zemine aktarılan gerilmelerin, dolayısıyla sistemde oluşacak olan deformasyonların, azalması yolu ile taşıma gücünün artması şeklinde açıklanabilmektedir. Geotekstil ile iyileştirme ise bu durumda da kritik yükseklik değeri üzerinde etkili olmamıştır. Ulaşılabilecek olan nihai kritik yükseklik değerleri incelendiğinde ise D1, D2, D3 dolgularında aynı, D4 dolgusunda ise en az değerde olacak şekilde sıralama yapılabilmektedir. Söz konusu durum göstermektedir ki, dolgunun kayma mukavemeti parametrelerinin azaltılması davranış üzerinde ciddi olumsuz etkilere yol açmakta ve bu durum şev eğimi etkisine nazaran daha baskın olmaktadır. Ayrıca MC malzeme modelinde yapılan analizlerde üst tabakanın sert olması ve tabaka kalınlığının artması ile elde edilebilecek kritik dolgu yüksekliği de sürekli olarak artmaktadır. Şekil 2(b $\left.b_{1}\right)$ 'de geosentetik malzeme ile iyileştirilen dolguya (D2) ait kritik yükseklik değeri; D1, D3, D4, D5 dolgularına göre üç kata varan farklılık göstermektedir ve tüm dolgularda yumuşak tabaka kalınlığının yükseklik üzerinde etkisi yok denecek kadar azdır. Şekil 2(b $\left.b_{2}\right)$ 'de D2 dolgusu en büyük kritik yükseklik değerini vermektedir. Diğer dolgularda ise 6 metreye varan sert tabaka kalınlığına kadar, kritik yükseklik değerleri aynı düzeyde artmakta ancak bu kalınlıktan sonra D3 $>$ D1 $>$ D5 $>$ D4 olacak şekilde değişim göstererek, 18 metre kalınlıktan sonra sabit bir yükseklik değerinde kalmaktadır. $\mathrm{Bu}$ davranış, gelişmiş modellerde (HS vb.) gerçekçi bir şekilde değerlendirilebilen deformasyon etkisinden kaynaklanmaktadır. Çünkü sert kil tabakasının küçük kalınlık değerlerinde gerilme etkisi yumuşak tabakaya transfer edilebilmekte ve deformasyonlar alttaki yumuşak zemin tabakası içinde yoğunlaşmaktadır. Alttaki tabakaya aktarılan gerilme artışı değerleri, artan kabuk tabakası kalınlığına bağlı olarak azaldıkça, alttaki yumuşak tabakada azalan deformasyonların kritik yüksekliği etkileme seviyesi düşmektedir. Kabuk tabakası kalınlığı yaklaşık olarak 18 metreye ulaştığında ise (bu problemde tanımlanan gerilme seviyeleri için geçerli olmak koşuluyla) temel zemini görevini esas olarak sert tabaka üstlenmektedir. Şekil 2(c $\left.c_{1}\right)$, $\left(d_{1}\right),\left(e_{1}\right)$ 'de de Şekil 2(b $\left.b_{1}\right)$ 'dekine benzer davranış görülmekte, geosentetik malzeme ile iyileştirilen dolguya ait kritik yükseklik değeri; D1, D3, D4, D5 dolgularına göre 2-3 kata varan farklılık sergilemektedir.

Tüm dolgularda üst tabakanın yumuşak kilden oluşması durumunda tabaka kalınlığının yükseklik üzerinde etkisi yok denecek kadar az olmaktadır. Şekil 2( $\left.c_{2}\right),\left(d_{2}\right),\left(e_{2}\right)$ 'de ise Şekil 2(b $\left.b_{2}\right)$ 'dekine benzer davranış görülmekte ve D2 dolgusu en büyük kritik yükseklik değerini vermektedir. Diğer dolgularda ise üstte 6 metreye varan sert tabaka kalınlığına kadar kritik yükseklik değerleri aynı değerlerde artmakta ancak bu kalınlıktan sonra D3 $>$ D1 $>$ D5 $>$ D4 olacak şekilde değişism göstererek 18 metre kalınlıktan sonra bir yükseklik değerinde sabitlenmektedir. Elde edilen yükseklik değerleri malzeme modellerine göre $\mathrm{MC}>\mathrm{HS}=\mathrm{HS}$ SS $>\mathrm{SS}>\mathrm{MCC}$ şeklinde değişiklik göstermektedir. $\mathrm{Bu}$ durum malzeme modeli farklılığının sistemin bütünsel davranışı üzerindeki etkisini ortaya koymaktadır. MC ile yapılan analizlerden elde edilen kritik dolgu yüksekliği değerinin diğer malzeme modelleri ile elde edilen değerlerden yüksek çıkmasının sebebi, diğer modellerde gerilme durumuna ve plastik bölgede rijitlik azalıșına bağlı olarak deformasyonların hesaplanabilmesi ve deformasyonlara dayalı olarak göçmeye varan davranışın takip edilebilmesidir. Ayrıca tüm şekillerden de görülmektedir ki, üstte sert kilin bulunduğu temel zemini profillerinde, üstte yumuşak kilin bulunduğu temel zemini profillerine göre daha yüksek dolgu inşa edilebilmektedir. Dolgu-temel zemini etkileşim probleminde dolgu davranışının daha gerçekçi bir şekilde ifade edilebilmesi için Dolgu 1-2-3-4-5'de HS, HS SS malzeme modelleri kullanılarak analizler tekrarlanmıştır. Çizelge 5'de MC, HS, HS SS malzeme modelleri ile tanımlanmıs Dolgu 1-2-3-4-5 için hesaplanan kritik yükseklik değerleri verilmiştir. Şekil 3'de ise D1'in temel zemini olarak üst tabakanın 1 metre yumuşak, 1 metre sert ve 18 metre yumuşak, 18 metre sert zeminden oluşması şeklindeki 4 durum için dolgu ve temel zemini malzeme modeli değişiminin kritik yükseklik değeri üzerindeki etkisi sütun grafikler ile özetlenmiştir. 

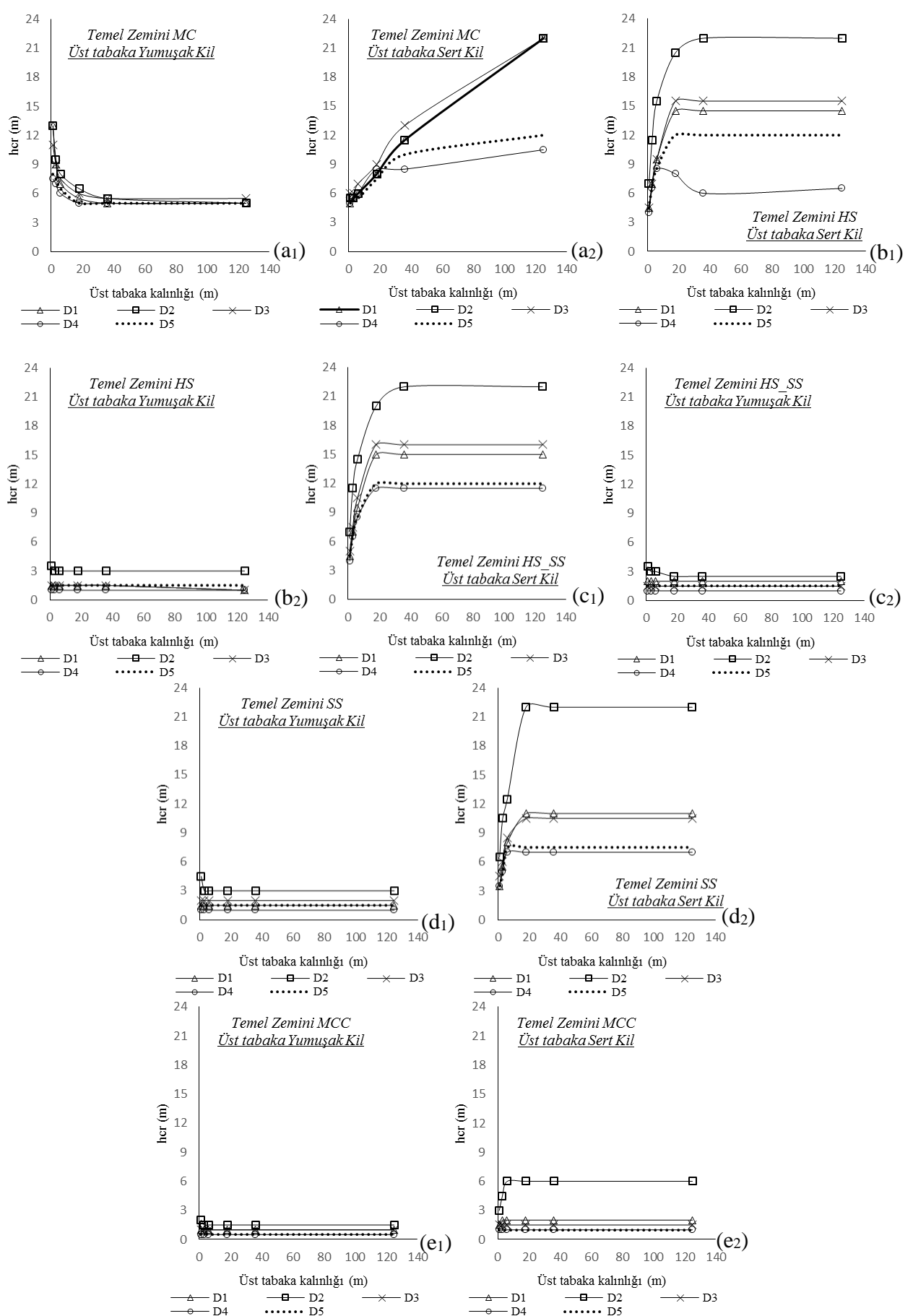

Şekil 2. Üst tabakanın yumuşak veya sert olması durumunda tabaka kalınlığının ve malzeme modelinin dolgu 1-2-3-4-5 için hesaplanan kritik yükseklik değeri üzerindeki etki 
Grafiklerin isimlendirmesinde kullanılan (1) alt indisi üst tabakada yumuşak kil bulunmasını, (2) alt indisi ise üst tabakada sert kil bulunmasını, (a) $1 \mathrm{~m}$ üst tabaka kalınlığını, (b) $18 \mathrm{~m}$ tabaka kalınlığını temsil etmektedir. Şekil 3(a $\left.a_{1}\right)$ 'de temel zemininin MC olması durumunda dolgunun farklı malzeme modelleri ile tanımlanmasının davranış üzerinde herhangi bir etkisi bulunmamaktadır. Hem dolgunun hem de temel zemininin farklı malzeme modellerinde tanımlanması durumunda ise $\mathrm{MC}$ ile yapılan analizlere göre 10 kata varan oranda farklı değerlere rastlanmıştır. $\mathrm{Bu}$ durum modeller arasında davranışı tanımlamak bakımından önemli farklılıkların bulunmasının sonucudur. MC modeli zemin davranışını tanımlamakta kullandığı mukavemet ve rijitlik parametreleriyle gerilme ve deformasyona dayalı bir analiz modeli değildir ve bu yapısıyla daha basit ve genel bir yaklaşım seviyesindedir. Problemin gerilme ve deformasyon davranışını gerçekçi bir şekilde takip etmek için daha gelişmiş seviyedeki modeller tercih edilmelidir.

Gelişmiş modellerde yapılan analizler incelendiğinde ise ulaşılabilecek olan kritik dolgu yüksekliği değeri üzerinde malzeme modelinin fazla etkili olmadığı ve ortalama kritik dolgu yüksekliğinin 1,6-2 metre aralığında olduğu hesaplanmıştır. Şekil 3(a $\left.a_{2}\right)$ 'de temel zemininin MC ile tanımlanması sonucu elde edilen yükseklik değerlerinin maksimum olduğu ve diğer modellerle yaklaşık olarak aynı yüksekliklerin elde edildiği görülmektedir.

Şekil 3( $\left.a_{1}\right)$ ve Şekil 3( $\left.a_{2}\right)$ karşılaştırıldığında ise sert zemin üzerinde bulunan 1 metre kalınlığındaki yumuşak zeminin taşıma gücünü azalttı̆̆ı; yumuşak zemin üzerinde bulunan 1 metre sert kilin ise taşıma gücünü ciddi oranda arttırdığı söylenebilmektedir. Yumuşak zemin yüzeyinde bulunan 1 metre kalınlığındaki kabuk tabakası dolgu yüklerini altta bulunan yumuşak zemin içerisine hapsederek yüklerin bu tabaka içerisinde daha geniş alana yayılmasını sağlamakta ve bu yolla, oluşan deplasman değerlerini azaltarak taşıma gücünü arttırmaktadır. Şekil 3(b $\left.b_{1}\right)$ 'de $\left(\mathrm{a}_{1}\right)$ 'dekine benzer bir davranış görülmekte ancak elde edilen değerler bakımından değerlendirme yapıldığında, yumuşak tabaka kalınlığı arttıkça ulaşılabilen kritik yükseklik değerinin özellikle MC malzeme modelinde azaldığı görülmüştür. Şekil 3(b $\left.b_{2}\right)$ 'de ise malzeme modeli farklılığı kritik yükseklik değerleri üzerinde önemli değişikliklere yol açmıştır. Maksimum kritik dolgu yüksekliği değerleri, temel zemininin ve dolgunun HS_SS malzeme modeli ile tanımlandığı durumlarda ortaya çıkmıştır. Maksimumdan minimuma olacak şekilde kritik yükseklik değerleri temel zemini malzeme modeline göre siralandığında HS SS $>$ HS $>$ SS $>$ MC $>$ MCC şeklindedir. Dolgu malzeme modelinin değişmesi en çok temel zemininin HS malzeme modeli ile tanımlandı $\breve{g}_{1}$ durumda belirginleşmiştir. Çizelge 6'da ve Şekil 3'de D1'in farklı malzeme modellerine ve farklı rijitlik değerine sahip temel zeminleri üzerinde yer alması durumunda üst tabaka kalınlıklarına bağlı olarak oluşan toplam deplasman değerleri sunulmuştur. Çizelge incelendiğinde üst tabakada sert kil olmas1 durumunda oluşan deplasman değerlerinin üstte yumuşak kil olmasına göre çok daha büyük olduğu ve bu durumun MCC model hariç tüm malzeme modellerinde geçerli olduğu söylenebilmektedir. Üst tabakanın yumuşak kil olması durumunda artan tabaka kalınlığı ile birlikte HS malzeme modelinde en fazla deplasman değeri elde edilirken MC malzeme modelinde artan tabaka kalınlığı ile doğrusal artım yapan deplasman değerleri görülmektedir. SS ve MCC malzeme modellerinde meydana gelen deplasman değerlerinde ise 6 metreden fazla kalınlıkta yumuşak kil olması durumunda deplasmanların artmadığı görülmektedir. Üstte sert kil bulunması durumu incelendiğinde ise HS model en büyük deplasman değerlerini sunarken tüm malzeme modelleri benzer bir davranış sergilemektedir. 18 metre tabaka kalınlığına kadar artan deplasman değerleri bu değerden fazla sert tabaka kalınlığında, azalmaya başlamaktadır. Görüldüğü üzere gerek temel zemini gerekse dolgu malzemesi olarak farklı malzeme modellerinin kullanılması, dolgu-zemin davranışının tanımlanmasında hem taşıma gücü hem de deformasyonlar açısından ciddi farklılıklar oluşmaktadır. $\mathrm{Bu}$ bağlamda, [9]'da farklı tür zeminlere, farklı tip yapısal uygulamalara, farklı yükleme koşullarına göre malzeme modellerinin uygulanabilirlikleri denetleyen çizelgeler düzenlenmiştir. 

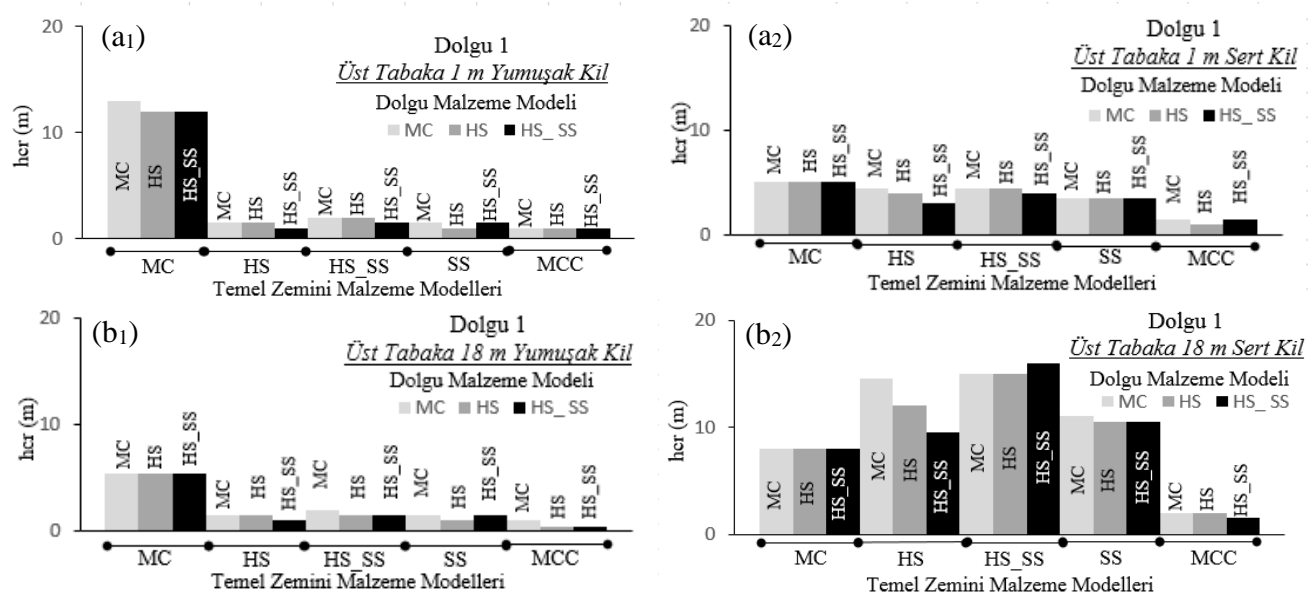

Şekil 3. Üst tabakanın yumuşak veya sert olması durumunda tabaka kalınlığının ve malzeme modelinin dolgu 1 için hesaplanan kritik yükseklik değeri üzerindeki etkisi

$\mathrm{Bu}$ çizelgelere göre analizlerdeki yumuşak kil tabakası SS, sert kil tabakası HS_SS ve dolgu HS_SS malzeme modeli parametreleriyle tanımlanarak Profil 1 ve Profil 2 için 1-6-18 metre değişken üst temel kalınlıkları ile analizler tekrarlanmış ve kritik yükseklik, toplam (u) -yatay $\left(u_{x}\right)$-düşey deplasman $\left(u_{y}\right)$ değerleri elde edilmiştir (Çizelge 7).

Analiz sonuçları değerlendirildiğinde; yumuşak kilin üstte bulunması durumunda temel zemini üst tabaka kalınlığının, ulaşılabilecek kritik yükseklik değeri üzerinde etkisinin olmadığı ancak yatay deformasyonları arttırdığg; sert kilin üstte bulunması durumunda ise temel zemini üst tabaka kalınlığı arttıkça elde edilebilecek kritik dolgu yüksekliğinin de ciddi oranda arttığı ancak oluşan toplam deplasmanların da tabaka kalınlığı ile birlikte fazlalaştığı görülmektedir. Söz konusu durum Şekil 5'de kritik yükseklikler için elde edilen toplam deformasyon ağı şekilleri ile vurgulanmıştır. Üst temel tabakasında yumuşak kil bulunması durumunda, tabaka kalınlığı ile orantılı olacak şekilde sert tabakaya ininceye kadar deformasyonlar tabaka içerisinde dağılarak sönümlenmektedir.

Şekillerden dolgu-temel zemini etkileşimi davranışı net bir şekilde seçilebilmekte ve temel zemininin deformasyonlarından ziyade dolgunun şevlerinde meydana gelen stabilite problemlerinden dolayı göçmelerin yaşandığ söylenebilmektedir. Üst temel tabakasında sert kil bulunması durumunda ise küçük üst tabaka kalınlıklarında, dolgu yüklemesi sebebi ile oluşan gerilmelerin tamamının alt tabakada bulunan yumuşak zemine nakledildiği ve elde olunan yüksek deformasyon değerlerinin yumuşak zeminden kaynaklandığı görülmektedir. Artan sert üst tabaka kalınlığı ile birlikte alt temel zemini tabakasında bulunan yumuşak kile nakledilen gerilmeler azalmakta, yükler sert kil tabakası tarafından karşılanmakta ve bu yolla yumuşak zeminden kaynaklanan deformasyonların sistem stabilitesini etkileme durumu ortadan kalkmaktadır. Artan üst sert tabaka kalınlığı ile beraber sistem stabilitesi dolgu deformasyonları ve davranışı tarafından yönlendirilmektedir.

\section{SONUÇLAR}

$\mathrm{Bu}$ makalede, farklı malzeme modelleri ile tanımlanan dolgu-tabakalanmış temel zemini ortamının etkileşimli davranışı, yapılan sonlu elemanlar analizleri ile parametrik olarak araştırılmıştır. Analizlerde kullanılan temel zemini için iki farklı rijitlik değerinde kil zeminin değişik sırlanmalardaki ve kalınlıklardaki kombinasyonları kullanılmıştır. 
Çizelge 5. Farklı malzeme modellerine ve tabakalanma durumlarına sahip temel zeminleri üzerinde yer alan MC, HS, HS SS malzeme modelleri ile tanımlanan Dolgu 1-2-3-4-5 için kritik yükseklik değerleri

\begin{tabular}{|c|c|c|c|c|c|c|c|c|c|c|c|}
\hline \multicolumn{12}{|c|}{ D 1} \\
\hline \multirow{3}{*}{ 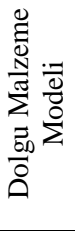 } & \multirow{3}{*}{$\begin{array}{c}\text { Temel Zemini } \\
\text { Malzeme Modeli } \\
\begin{array}{c}\text { Üst Tabaka Kalınlığ } \\
\text { (m) }\end{array}\end{array}$} & \multicolumn{2}{|c|}{ MC } & \multicolumn{2}{|c|}{ HS } & \multicolumn{2}{|c|}{ HS_SS } & \multicolumn{2}{|c|}{ SS } & \multicolumn{2}{|c|}{ MCC } \\
\hline & & YK & SK & YK & SK & YK & SK & YK & SK & YK & SK \\
\hline & & \multicolumn{2}{|c|}{$\mathrm{h}_{\mathrm{cr}}(\mathrm{m})$} & \multicolumn{2}{|c|}{$\mathrm{h}_{\mathrm{cr}}(\mathrm{m})$} & \multicolumn{2}{|c|}{$\mathrm{h}_{\mathrm{cr}}(\mathrm{m})$} & \multicolumn{2}{|c|}{$\mathrm{h}_{\mathrm{cr}}(\mathrm{m})$} & \multicolumn{2}{|c|}{$\mathrm{h}_{\mathrm{cr}}(\mathrm{m})$} \\
\hline \multirow{2}{*}{ 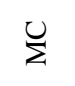 } & 1 & 13 & 5 & 1,5 & 4,5 & 2 & 4,5 & 1,5 & 3,5 & 1 & 1,5 \\
\hline & 18 & 5,5 & 8 & 1,5 & 14,5 & 2 & 15 & 1,5 & 11 & 1 & 2 \\
\hline \multirow{2}{*}{$\tilde{I}$} & 1 & 12 & 5 & 1,5 & 4 & 2 & 4,5 & 1 & 3,5 & 1 & 1 \\
\hline & 18 & 5,5 & 8 & 1,5 & 12 & 1,5 & 15 & 1 & 10,5 & 0,5 & 2 \\
\hline \multirow{2}{*}{$n^{\prime} n$} & 1 & 12 & 5 & 1 & 3 & 1,5 & 4 & 1,5 & 3,5 & 1 & 1,5 \\
\hline & 18 & 5,5 & 8 & 1 & 9,5 & 1,5 & 16 & 1,5 & 10,5 & 0,5 & 1,5 \\
\hline \multicolumn{12}{|c|}{ D 2} \\
\hline \multirow{2}{*}{ 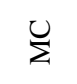 } & 1 & 13 & 5,5 & 3,5 & 7 & 3,5 & 7 & 4,5 & 6,5 & 2 & 3 \\
\hline & 18 & 6,5 & 8 & 3 & 20,5 & 2,5 & 14,5 & 3 & 22 & 1,5 & 6 \\
\hline \multirow{2}{*}{$\mathscr{I}$} & 1 & 12,5 & 5 & 4 & 6 & 4,5 & 6 & 4 & 6 & 1,5 & 3 \\
\hline & 18 & 5,5 & 7,5 & 3 & 15 & 3 & 16 & 2,5 & 11 & 1,5 & 4 \\
\hline \multirow{2}{*}{$\tilde{n}^{\prime} \approx$} & 1 & 12 & 5 & 3,5 & 3,5 & 3,5 & 4,5 & 3,5 & 4 & 1,5 & 2 \\
\hline & 18 & 5,5 & 8 & 2,5 & 11 & 2,5 & 15 & 2,5 & 11 & 1,5 & 4 \\
\hline \multicolumn{12}{|c|}{ D 3} \\
\hline \multirow{2}{*}{$\dot{\Sigma}$} & 1 & 11,5 & 6 & 1,5 & 4,5 & 1,5 & 5 & 2 & 4,5 & 1 & 1,5 \\
\hline & 18 & 6 & 9 & 1,5 & 15,5 & 1,5 & 16 & 2 & 10,5 & 1 & 1,5 \\
\hline \multirow{2}{*}{ 弪 } & 1 & 10,5 & 5,5 & 1,5 & 4,5 & 1,5 & 5 & 1,5 & 4 & 0,5 & 1,5 \\
\hline & 18 & 6 & 9 & 1,5 & 12 & 1,5 & 16 & 1,5 & 10 & 0,5 & 1,5 \\
\hline \multirow{2}{*}{$\tilde{\Omega}^{\prime} \approx$} & 1 & 10 & 5,5 & 1 & 3 & 1,5 & 4 & 1,5 & 3,5 & 1 & 1 \\
\hline & 18 & 6 & 9 & 1 & 13 & 1,5 & 16 & 1,5 & 10 & 0,5 & 1,5 \\
\hline & & & & & & & & & & & \\
\hline 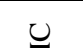 & 1 & 7,5 & 5 & 1 & 4 & 1 & 4 & 1 & 3,5 & 0,5 & 1 \\
\hline$\Sigma$ & 18 & 5 & 8,5 & 1 & 8 & 1 & 11,5 & 1 & 7 & 0,5 & 1 \\
\hline$\cong$ & 1 & 7 & 5 & 1 & 4 & 1 & 4 & 1 & 3,5 & 0,5 & 1 \\
\hline$I$ & 18 & 5 & 7,5 & 1 & 6,5 & 1 & 10 & 1 & 7 & 0,5 & 1 \\
\hline$n^{\prime} n$ & 1 & 7 & 5 & 1 & 3 & 1 & 4 & 1 & 3 & 0,5 & 1 \\
\hline$\pi$ & 18 & 5 & 8 & 0,5 & 6 & 1 & 10 & 1 & 7 & 0,5 & 1 \\
\hline & & & & & & & & & & & \\
\hline U & 1 & 8 & 5 & 1,5 & 4,5 & 1,5 & 4,5 & 1,5 & 3,5 & 0,5 & 1 \\
\hline$\Sigma$ & 18 & 5 & 7,5 & 1,5 & 12 & 1,5 & 12 & 1,5 & 7,5 & 0,5 & 1 \\
\hline$\approx$ & 1 & 8,5 & 5 & 1,5 & 4 & 1,5 & 4 & 1,5 & 3,5 & 0,5 & 1,5 \\
\hline$I$ & 18 & 5 & 7,5 & 1,5 & 10,5 & 1,5 & 12 & 1,5 & 7,5 & 0,5 & 1,5 \\
\hline $\ln$ & 1 & 8 & 5 & 1 & 3 & 1,5 & 4 & 1,5 & 3,5 & 0,5 & 1,5 \\
\hline$\pi$ & 18 & 5 & 7,5 & 1 & 9 & 1,5 & 11,5 & 1,5 & 7,5 & 0,5 & 1,5 \\
\hline
\end{tabular}


Çizelge 6. Dolgu 1'in farklı malzeme modellerine ve farklı rijitlik değerine sahip temel zeminleri üzerinde yer alması durumunda üst tabaka kalınlıklarına bağlı olarak oluşan toplam deplasman değerleri

\begin{tabular}{|c|c|c|c|c|c|c|c|c|c|c|}
\hline \multirow{2}{*}{$\begin{array}{c}\text { DOLGU } \\
\text { (MC) }\end{array}$} & \multicolumn{9}{|c|}{ Temel Zemini Malzeme Modeli } \\
\cline { 2 - 13 } & \multicolumn{2}{|c|}{ MC } & \multicolumn{2}{c|}{ HS } & \multicolumn{2}{c|}{ SS } & \multicolumn{2}{c|}{ MCC } & \multicolumn{3}{c|}{ HS_SS } \\
\hline $\begin{array}{c}\text { Üst tabaka } \\
\text { kalınlığ } 1(\mathrm{~m})\end{array}$ & $\mathrm{YK}$ & $\mathrm{SK}$ & $\mathrm{YK}$ & $\mathrm{SK}$ & $\mathrm{YK}$ & $\mathrm{SK}$ & $\mathrm{YK}$ & $\mathrm{SK}$ & $\mathrm{YK}$ & SK \\
\hline & $\mathrm{u}(\mathrm{m})$ & $\mathrm{u}(\mathrm{m})$ & $\mathrm{u}(\mathrm{m})$ & $\mathrm{u}(\mathrm{m})$ & $\mathrm{u}(\mathrm{m})$ & $\mathrm{u}(\mathrm{m})$ & $\mathrm{u}(\mathrm{m})$ & $\mathrm{u}(\mathrm{m})$ & $\mathrm{u}(\mathrm{m})$ & $\mathrm{u}(\mathrm{m})$ \\
\hline 1 & 0,3195 & 1,078 & 0,4107 & 4,621 & 0,05075 & 0,249 & 0,24 & 0,1 & 0,5952 & 0,7285 \\
\hline 3 & 0,2141 & 1,75 & 0,8365 & 9,588 & 0,1 & 0,4307 & 0,3369 & 0,2604 & 0,8818 & 2,327 \\
\hline 6 & 0,1866 & 3,252 & 0,8712 & 10,43 & 0,1218 & 0,628 & 0,4073 & 0,4073 & 0,1 & 1,775 \\
\hline 18 & 0,2645 & 3,362 & 0,8726 & 3,213 & 0,1373 & 0,5455 & 0,4617 & 0,1523 & 2,766 & 1,804 \\
\hline 36 & 0,3824 & 2,537 & 0,8732 & 2,148 & 0,147 & 0,3358 & 0,4609 & 0,1566 & 2,463 & 0,5406 \\
\hline
\end{tabular}
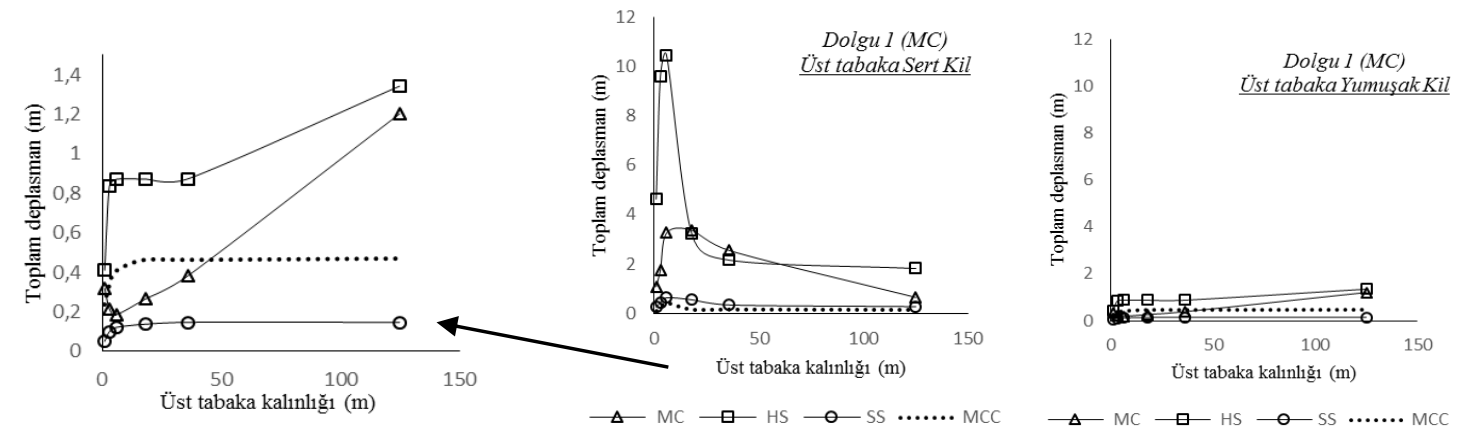

Şekil 4. Dolgu 1 için toplam deplasman değerlerinin üst tabaka kalınlığına bağlı değişimi

Çizelge 7. Dolgunun HS_SS, yumuşak kilin SS ve sert kilin HS_SS malzeme modelleri ile tanımlanması durumunda elde edilen kritik yükseklik, toplam-yatay-düşey deplasman değerleri

\begin{tabular}{|c|c|c|c|c|c|}
\hline 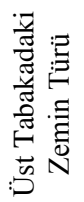 & $\begin{array}{l}\text { Üst Tabaka } \\
\text { Kalınlığ }(\mathrm{m})\end{array}$ & $\mathrm{h}_{\mathrm{cr}}(\mathrm{m})$ & $\mathrm{u}(\mathrm{m})$ & $\mathrm{u}_{\mathrm{x}}(\mathrm{m})$ & $\mathrm{u}_{\mathrm{y}}(\mathrm{m})$ \\
\hline \multirow{3}{*}{$\ddot{x}$} & 1 & 1,5 & 0,03668 & 0,03663 & $2,49 \mathrm{E}-03$ \\
\hline & 6 & 1,5 & 0,132 & 0,132 & 0,02028 \\
\hline & 18 & 1,5 & 0,1553 & 0,1553 & 0,03114 \\
\hline \multirow{3}{*}{$\ddot{v}$} & 1 & 4,5 & 0,6633 & 0,6249 & 0,2554 \\
\hline & 6 & 9 & 0,7439 & 0,6185 & 0,2321 \\
\hline & 18 & 15 & 0,9715 & 0,4935 & 0,1359 \\
\hline
\end{tabular}



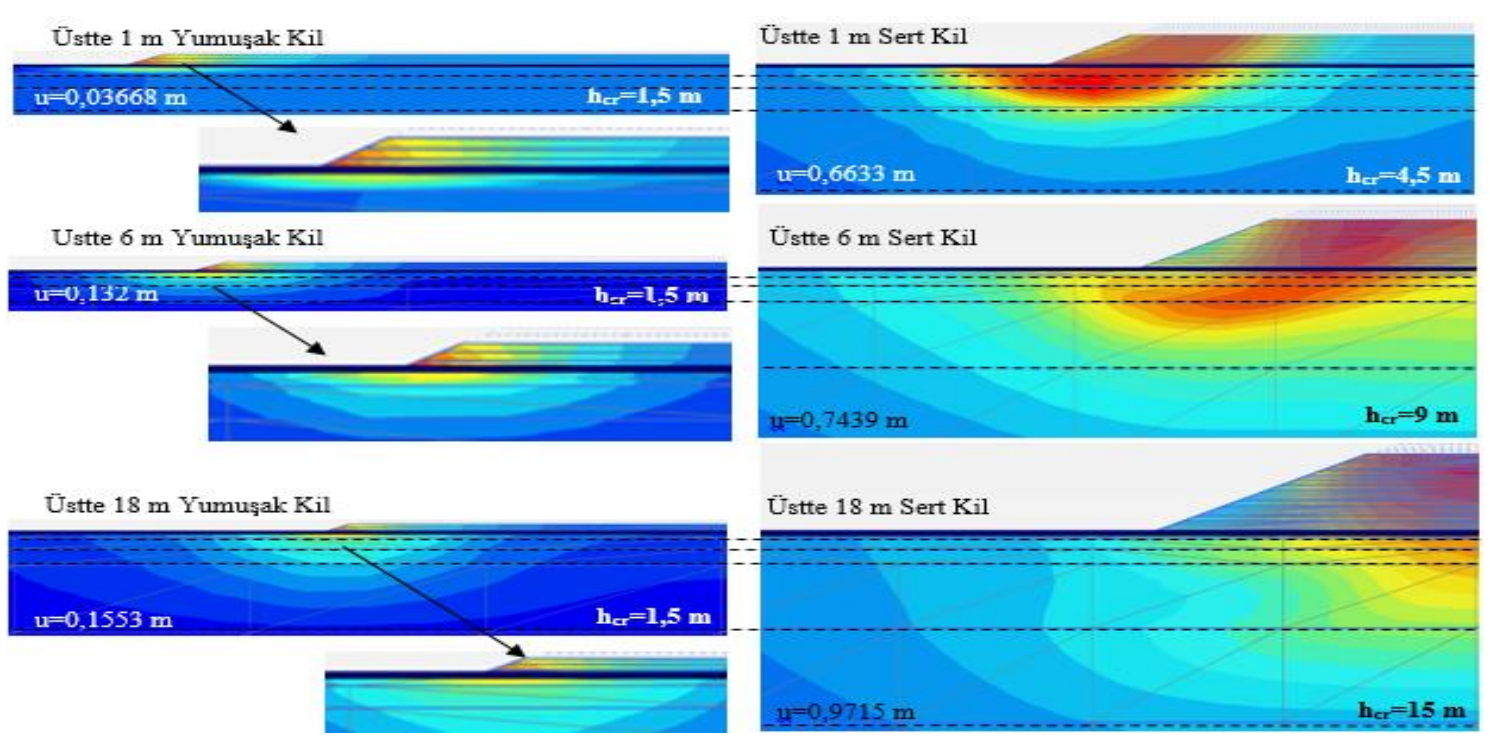

Şekil 5. Dolgunun HS_SS, yumuşak kilin SS ve sert kilin HS_SS malzeme modelleri ile tanımlanması durumunda elde edilen deformasyon ağ

Seçilen dolgu malzemesinin ve güçlendirmenin sistem davranışına etkisini belirlemek için birim hacim ağırlık ve kayma mukavemeti parametreleri değerlerinde yapılan değişiklikler ile analizler tekrarlanmıştır. Tüm analizlerde drenajsız koşullarda dolgunun göçmeden inşa edilebileceği maksimum yükseklik değerleri elde edilmiştir. Seçilen bazı özel durumlar için ise göçme mekanizmaları ve deplasman değerleri incelenmiş ve bu analizler 1şığında aşağıdaki sonuçlara ulaşılmıştır:

(Yapılan değerlendirmeler sadece seçilen çalışma koşullarına ve Plaxis programında yapılan analizlere bağlıdır). Dolgu-temel sisteminin tanımlanmasında kullanılan malzeme modellerinin seçimi ve malzeme modellerine göre kullanılacak geoteknik parametrelerin hesaplanması makalenin odak noktasıdır. Yapılan analizler sonucunda söz konusu model ve parametre farklılıklarının etkisi belirgin bir şekilde görülmüştür. Kullanılan malzeme modellerinden MC, zemin davranışını tanımlamakta kullandığı mukavemet ve rijitlik parametreleriyle gerilme ve deformasyona dayalı bir analiz modeli değildir ve bu yapısıyla daha basit ve genel bir yaklaşım seviyesindedir.
Dolgu-temel zemini etkileşimi gibi zemin-yap1 etkileşiminin söz konusu olduğu geoteknik uygulamalarında gerilme ve deformasyon davranışını gerçekçi bir şekilde takip etmek için daha gelişmiş seviyedeki modeller kullanılmalıdır. Kullanilacak olan malzeme modelinin seçilmesinde en önemli parametre, kullanılan yapısal elemanın (dolgu-zemin vb.) türüne uygunluktur. Bunun yanı sıra malzeme modelinin kullanım amacına ve yükleme koşullarına uygunluğu da denetlenmesi gereken önemli olgulardandır. HS modelin her türlü malzemenin modellenmesinde uygun olduğu ve kullanmış olduğu üç adet rijitlik parametresi ile gerçeğe daha uygun davranış sergileyeceği, HS_SS malzeme modelinin ise dolgu malzemesi gibi granüler yapıda olan veya aşırı konsolide olan malzemelerde kullanımının daha uygun olduğu yapılan analizler sonucunda görülmüştür. SS model yumuşak veya organik zeminlerin tanımlanmasında tercih edilmesi gereken üst düzey bir modeldir.

Model, makale kapsamında kullanılan yumuşak kil zeminin tanımlanmasinda uygundur, sert zeminlerin bu model ile tanımlanması diğer 
modellere göre daha az kritik dolgu yüksekliği elde edilmesine neden olmuştur. MCC model SS model ile aynı disiplinde çalışmakta ancak normal konsolide killer dişındaki zeminlerin tanımlanmasında kullanılmaları durumunda çok büyük kayma gerilmelerinin oluşmasına neden olarak daha düşük yükleme seviyelerinde göçme davranış1 sergilemektedirler ve bu yolla inşa edilebilecek dolgu yüksekliğini az hesaplayarak dolgu-temel zemini davranışını gerçekçi bir şekilde yansıtamamaktadır. Makalenin diğer bir odak noktası ise dolgunun farklı malzeme parametreleri ve değişik uygulamalar ile inşasının, kritik yükseklik üzerindeki etkisinin değerlendirilmesidir. Dolgunun gerek mukavemet parametreleri gerekse şev eğimi açısından kendi stabilitesini sağlayabilecek yeterlilikte olması durumunda, dolgu-temel zemini ortamının davranışını yönlendiren temel etken yumuşak zemin sebebi ile meydana gelen deformasyonlar olmaktadır. Dolgu kayma mukavemeti parametrelerinin azaltılması sonucunda, sistem davranışı sadece yumuşak temel zemininin deformasyonlarından etkilenmeyip, özellikle dolgu şev topuğunda biriken deplasmanlar, sitemi göçmeye götürebilmektedir. Dolgu birim hacim ağırlığının azaltılması durumunda ise temel zeminine etkiyen yüklerin azalması sonucu yumuşak zemin içerisinde meydana gelen yer değiştirmeler azalmakta ve elde edilebilen kritik dolgu yüksekliği değeri ile birlikte sistemin güvenlik sayısı da artmaktadır. Dolgu-zemin ara yüzeyine güçlendirme amacı ile serilen geotekstil malzeme, karşıladığı çekme gerilmeleri ile sistem dayanımını arttırmakta ve bu yolla ulaşılabilecek olan kritik dolgu yüksekliği değeri de (MC malzeme modeli hariç) ciddi oranda artmaktadır.

\section{TEŞEKKÜR}

Bu çalıșma 56243 ve 46366 nolu UDP ve 20589 nolu doktora tez projeleri ile İstanbul Üniversitesi Bilimsel Araştırma Projeleri Birimi tarafından desteklenmiştir, teşekkür ederiz.

\section{KAYNAKLAR}

1. Wen, Y., Zhou, J.Jia, M., 2007. Critical Edge Pressure of Soft Clay Foundation Considering
Closure Effect, Rock and Soil Mechanics, 28(8).

2. Deb, K., Dey, A., Chandra, S., 2007. Modeling of Layered Soil System, FIYGEC.

3. Akbay Arama, Z., Yaramış, M., Çinicioğlu, S.F., 2013. Tabakalaşmış Zeminler Üzerinde Yer Alan Genişletilmiş Yol Dolgularının Nümerik Analizi, 5. Geoteknik Sempozyumu.

4. Akbay Arama, Z., Çinicioğlu, S. F., 2014. Analysis of the Influence of Embankment Widening on Layered Foundation Soils, XV (DECGE).

5. Akbay Arama, Z., Çinicioğlu, S.F., Öser, C., 2015. Analysis of Embankment Widening Problems, XVI European Conferance on Soil Mechanics and Geotechnical Engineering.

6. Akbay Arama, Z., Çinicioğlu, S. F., 2015. Tabakalanmış Killi Zeminler Üzerinde Yer Alan Dolgularda Kritik Yükseklik, 6. Geoteknik Sempozyumu.

7. Australia Queensland Government Department of Transport and Main Roads, 2015. Manual Geotechnical Design Standart.

8. Surarak, C., 2010. Geotechnical Aspects of the Bangkok MRT Blue Line Project, GU School of Engineering, $\mathrm{PhD}$ thesis.

9. Brinkgreve, R. B. J., Kumarswamy, S., Swolfs, W. M., 2011. Plaxis Material Models Manual.

10. Brinkgreve, R. B. J., Engin, E., Engin, H. K., 2010. Validation of Empirical Formulas to Derive Model Parameters for Sands, Numerical Methods in Geotechnical Engineering, London.

11. Boogert, T.D., Duijnen, P.V., Eekelen, S.V., 2012. Numerical Analysis of Geosynthetic Reinforced Piled Embankment Scale Model Tests, Delft.

12. Surarak, C., Likitlersuang, S., Wanatowski, D., Balasubramaniam, A., Oh. E., Guan, H., 2012. Stiffness and Strenght Parameters for Hardening Soil Model of Soft and Stiff Bangkok Clays, Soils and Foundations, 52(4), 682-697. 